\title{
Human granulosa cells are a site of sulphatase activity and are able to utilize dehydroepiandrosterone sulphate as a precursor for oestradiol production
}

\author{
J Bonser, J Walker, A Purohit ${ }^{1}$, M J Reed ${ }^{1}$, B V L Potter ${ }^{2}$, \\ D S Willis, S Franks and H D Mason
} Department of Reproductive Science and Medicine, Imperial College School of Medicine, St Mary's Hospital, Paddington, London W2 1PG, UK
${ }^{1}$ Section of Endocrinology and Metabolism, Imperial College School of Medicine, St Mary's Hospital, Paddington, London W2 1PG, UK
${ }^{2}$ Wolfson Laboratory of Medicinal Chemistry, Department of Pharmacy and Pharmacology, University of Bath, Bath BA2 7AY, UK
(Requests for offprints should be addressed to H D Mason who is now at the Department of Obstetrics and Gynaecology and Department of Physiology,
St George's Hospital Medical School, Tooting, London SW17 ORE, UK)

\begin{abstract}
Dehydroepiandrosterone sulphate (DHEAS) is the most abundant androgen in the circulation and in ovarian follicular fluid. A steroid sulphatase accepting DHEAS as a substrate has been identified in the follicle, but the cellular location has not been determined. As DHEAS is also a potential source of oestrogen for endocrine-dependent tumours, a potent steroid sulphatase inhibitor oestrone-3O-sulphamate (EMATE) has been developed which inhibits this activity in rat liver and mammary tumour. The aim of this study was to investigate human granulosa cells as a site of steroid sulphatase activity, to determine whether DHEAS can be utilized as a precursor for oestrogen synthesis and to investigate the inhibitory capacity of EMATE in these cells. Conversion of DHEAS to DHEA was assessed in luteinized granulosa cells by tritiated steroid assay following incubation with or without LH or insulin and steroid accumulation in the medium measured by RIA. The effects of EMATE were assessed by addition of a range of doses during the measurement
\end{abstract}

of conversion of DHEAS to DHEA. Cells from three sizes of small follicles from an unstimulated ovary were also assessed for their ability to produce oestradiol from DHEAS.

Sulphatase enzyme activity was present in all cells; the mean conversion of tritiated DHEAS to DHEA was 50\% (range 4-65\%). LH and EMATE inhibited and insulin stimulated this activity. Addition of DHEAS to granulosa cells caused a dose-dependent increase in oestradiol and androstenedione production with no change in progesterone concentration. LH increased the accumulation of oestradiol in the medium. DHEAS also stimulated oestradiol production by granulosa cells from small follicles. This is the first demonstration that granulosa cells are a site of sulphatase activity and that DHEAS can be utilized as a substrate for androstenedione and oestrogen production. This may be of physiological importance for both normal folliculogenesis and oestrogen-dependent tumour growth. Journal of Endocrinology (2000) 167, 465-471

\section{Introduction}

Dehydroepiandrosterone sulphate (DHEAS) is the most abundant androgen in the circulation and is mostly adrenal in origin. In the adult, plasma concentrations vary according to gender and gradually decline with age in both sexes (for a review, see Haning 1995). The involvement of the ovary in its synthesis is suggested by a sharp decline in serum levels in women with premature ovarian failure or following oophorectomy (Cumming et al. 1982).

DHEAS is also the most abundant steroid in follicular fluid of preovulatory follicles being present at micromolar levels (Dehenin et al. 1987). The precise role of DHEAS in ovarian steroidogenesis remains to be elucidated but its presence at high concentrations has prompted several in vivo investigations into its possible role as an oestrogen precursor. As long ago as 1965 infusion of tritiated DHEAS was reported to result in urinary excretion of tritiated androstenetriol monosulphate in humans (Baulieu et al. 1965), but detailed studies of its role as a prehormone were not completed at this time due to methodological problems.

In a series of more recent investigations by Haning et al. (1985, 1989, 1991), DHEAS was infused into patients and the concentrations of tritiated steroids in the follicular fluid calculated. Although appreciable amounts of androgen were produced, the levels of oestrogens were low, suggesting that the latter were preferentially derived from androstenedione. It has recently been concluded that measurements of DHEAS metabolites in serum did not 
directly reflect events occurring within steroidogenic tissues (Haning 1995).

In in vitro studies, the levels of oestrogens and testosterone derived from DHEAS were higher in follicles in the follicular phase than in the luteal phase (Dehenin et al. 1987). This may mean that DHEAS is utilized by the ovary as a precursor for oestradiol synthesis mainly in the follicular phase when the requirement for androgen as an aromatase substrate is highest.

Conversion of DHEAS to DHEA requires enzymatic removal of the sulphate group. Previous studies have identified a steroid sulphatase that accepts DHEAS as a substrate in the ovarian follicle, stroma and corpus luteum (Haning et al. 1990), but the cellular localization of this enzyme remains to be determined.

Because of the possible importance of DHEA and oestrone in the provision of substrate for endocrinedependent tumours, a series of steroid sulphatase inhibitors has been designed from modifications of the enzyme substrate oestrone sulphatase (Reed et al. 1994). These have been shown to inhibit oestrone sulphatase activity in vitro. The most effective of these is a range of nonphosphate-based sulphate surrogates of which oestrone-3O-sulphamate (EMATE) proved to be the most potent (Purohit et al. 1995a). EMATE inhibits oestrone and DHEA sulphatase activity in rat liver and mammary tumour by more than 98\% (Purohit et al. 1995b).

The aim of this study was to determine whether luteinized human granulosa cells are a site of steroid sulphatase activity and, if so, to examine whether granulosa cells from both antral and preovulatory follicles are capable of utilizing DHEAS as a precursor for oestradiol production. We also wished to assess the efficacy of EMATE as an inhibitor of sulphatase activity in these cells.

\section{Methods}

\section{Granulosa cell culture}

Granulosa cells were obtained from patients undergoing treatment for in vitro fertilization. All patients had pituitary desensitization with luteinizing hormone-releasing hormone (LHRH) agonist followed by stimulation with human menopausal gonadotrophin (Hardy et al. 1995). Oocytes were separated from follicular fluid and flush solution. Granulosa cells were separated from other cellular debris and blood cells on a Percoll gradient. Briefly, the protocol was as follows: the flush was divided between $25 \mathrm{ml}$ tubes and centrifuged at 1000 r.p.m. at $25^{\circ} \mathrm{C}$ for $5 \mathrm{~min}$. The pellet was separated from the supernatant and resuspended in phosphate buffer solution at $37^{\circ} \mathrm{C}$. Cell suspensions were pooled and re-centrifuged until a blood-granulosa cell suspension of $8 \mathrm{ml}$ was achieved. A $50 \%$ Percoll (Sigma Chemical Co., Poole, Dorset, UK) solution was prepared by adding $8.9 \mathrm{ml}$ Percoll, $1 \mathrm{ml}$ of $10 \times$ Medium 199 (Gibco BRL, Paisley, Strathclyde,
UK), $100 \mu \mathrm{l} \mathrm{NaHCO}$ at 7.5\% and $10 \mathrm{ml}$ of Medium 199 at $37^{\circ} \mathrm{C}$ containing penicillin, streptomycin and glutamine (Gibco). The Percoll solution was then sterilized by filtration and divided into $4 \times 15 \mathrm{ml}$ conical tubes. Two millilitres of cell suspension were layered onto each tube followed by centrifugation at 1330 r.p.m. at $25^{\circ} \mathrm{C}$ for $20 \mathrm{~min}$. The granulosa cells were aspirated from the Percoll-PBS interface, washed in $15 \mathrm{ml}$ Medium 199 at $37^{\circ} \mathrm{C}$ and centrifuged at 100 r.p.m. at $25^{\circ} \mathrm{C}$ for $5 \mathrm{~min}$. This washing of granulosa cells was then repeated. The pellet of cells was resuspended in $1 \mathrm{ml}$ of Medium 199 and dispersed using a $200 \mu \mathrm{l}$ pipette tip and a microsyringe. Cells were counted on a haemocytometer using Trypan blue exclusion to assess viability.

Cells were plated at $10^{5}$ viable cells per well in $24-$ well plates in $1 \mathrm{ml}$ of Medium 199 for the sulphatase enzyme measurement or in $0.5 \mathrm{ml}$ for the measurement of steroid production. Cells were cultured for $48 \mathrm{~h}$ with the addition of $1 \%$ fetal calf serum (FCS) and antibiotics (Gibco) after which the medium was collected, the cells washed and then incubated in serum-free medium for a further time period with the addition of the test substances. All experiments were carried out in quadruplicate wells unless otherwise stated.

In one experiment, cells were obtained from a woman undergoing bilateral salpingo-oophorectomy for nonovarian benign gynaecological disease. Ethical approval had been granted by the local ethics committee and the patient had given informed consent. This patient had taken no treatment likely to affect ovarian function for at least 3 months prior to surgery. Follicles were dissected intact from the stroma and cells cultured without preincubation as previously described (Mason et al. 1990). Briefly, the diameter of follicles was measured, follicular fluid aspirated and after incision of the follicle the granulosa cells were flushed from the surface. The cumulusoocyte complex was removed if visualized and granulosa cells were collected, washed and plated at $5 \times 10^{4}$ viable cells per well in a $200 \mu \mathrm{l}$ volume of serum-free Medium 199. Cells were pooled from six follicles of $5 \mathrm{~mm}$ or less in diameter and incubated separately from cells from a $7 \mathrm{~mm}$ follicle and a $9 \mathrm{~mm}$ follicle.

\section{Sulphatase assay}

Sulphatase enzyme activity was assessed by measuring the conversion of tritiated DHEAS (DuPont Company, Wilmington, DE, USA) to DHEA with the addition of $\left[{ }^{14} \mathrm{C}\right]$ DHEA as a recovery marker to monitor losses due to the possibility that some of the tritiated DHEA might be converted into other metabolites. The method used was that of Duncan et al. (1993) which consists of several stages. Initially medium was removed from the cells and replaced with $0.5 \mathrm{ml}$ buffer solution containing tritiated DHEAS $\quad\left(0 \cdot 25 \mu \mathrm{Ci} / 10^{5} \quad\right.$ cells $)$ and $\left[{ }^{14} \mathrm{C}\right]$ DHEA $(0 \cdot 0023 \mu \mathrm{Ci}, 90 \mathrm{nM})$. The specific activity of the tritiated 
DHEAS was $16 \mathrm{Ci} / \mathrm{mmol}$ and of $\left[{ }^{14} \mathrm{C}\right] \mathrm{DHEA} 51 \mathrm{mCi} /$ mmol, with $31 \mathrm{nM}$ DHEAS used as substrate. After the determined time period, $0.4 \mathrm{ml}$ of the solution was removed to a test tube and toluene added to extract all non-sulphated product, i.e. DHEA and metabolites and $\left[{ }^{14} \mathrm{C}\right]$ DHEA. An aliquot of this mixture was then counted and the amount of product formed calculated according to the amount of tritiated substrate added and the \% recovery of the $\left[{ }^{14} \mathrm{C}\right]$ DHEA. A series of wells without cells was included in each experiment to allow for non-specific conversion ('blanks'). The product was identified in validation studies by thin-layer chromatography using the system ethyl acetate-methyl alcohol $(80: 20 \mathrm{v} / \mathrm{v})$. In this system, steroid sulphates remain at the origin. Mean (s.E.) percent recovery was $87 \cdot 1(3 \cdot 2)$.

\section{Experimental protocol}

A series of experiments was performed to assess the optimum time for induction of the sulphatase enzyme in the granulosa cells and for conversion of added DHEAS to DHEA. In a second series of experiments, following the $48 \mathrm{~h}$ pre-incubation period, cells were incubated with a range of doses of either purified human pituitary $\mathrm{LH}$ $(0 \cdot 25-10 \mathrm{ng} / \mathrm{ml}$, Endocrine Services, Bidford-on-Avon, Warwickshire, UK), or a range of doses of human recombinant insulin (Boehringer-Mannheim, Lewes, E. Sussex, UK) for a further $48 \mathrm{~h}$. In a third series of experiments the direct effect of the sulphatase inhibitor EMATE on the conversion of DHEAS to DHEA was assessed by addition of a range of doses at the assay stage. Each experiment was performed at least three times.

\section{Production of oestradiol from DHEAS}

Cells were incubated at $10^{5}$ viable cells per well for $48 \mathrm{~h}$ in medium containing $1 \%$ FCS, after which medium was removed and the experimental protocol described above was followed. Cells were initially incubated with a range of doses of DHEAS $(0 \cdot 05-1 \cdot 0 \mu \mathrm{M})$ for various lengths of time to determine the optimum conditions for oestradiol, progesterone and, in one case, androstenedione production. Steroids were measured in the medium at the end of the experiment by RIA as previously described (Gilling-Smith et al. 1994, Mason et al. 1994).

Cells were then incubated with a range of doses of DHEAS for the optimum time. The effect of a range of doses of LH and follicle-stimulating hormone (FSH) $(0 \cdot 25-10 \mathrm{ng} / \mathrm{ml}$, Endocrine Services) was then determined. Finally the effects of DHEAS on progesterone and oestradiol production by granulosa cells from an unstimulated ovary were assessed.

Sulphatase activity in the granulosa cells was expressed as percent control. Bars in Figs 1 and 2 represent the mean and standard error of at least quadruplicate wells in the experiments in luteinized cells and of triplicate wells in the experiment on cells from an unstimulated ovary. Comparisons between dose-response curves were performed by analysis of variance and between individual points by Student's $t$-test.

\section{Results}

\section{Sulphatase enzyme activity}

Sulphatase enzyme activity was present in all wells containing granulosa cells from all sources as assessed by conversion of DHEAS to DHEA following removal of the test substances. There was a wide range of activity between luteinized cells from different patients. The time course experiments (data not shown) revealed that maximal activity was measured with an incubation period of $4 \mathrm{~h}$. This incubation time was chosen for all further assays. The median conversion of DHEAS to DHEA at this time point was $50 \%$ (range $4-65 \%, n=20$ ).

LH significantly inhibited sulphatase activity in luteinized granulosa cells in a dose-dependent manner (Fig. 1a), reducing activity to $85 \%$ of baseline at $5 \mathrm{ng} / \mathrm{ml}$. In contrast, insulin caused stimulation of the enzyme activity by $30 \%$ at $10 \mathrm{ng} / \mathrm{ml}$ (Fig. 1b). Both insulin and $\mathrm{LH}$ stimulated progesterone production by the cells in a dose-dependent manner in the same experiments (data not shown). Addition of EMATE during the sulphatase assay suppressed activity dose-dependently with significant inhibition seen at the lowest dose tested and maximum inhibition occurring between $0 \cdot 1$ and $1 \cdot 0 \mu \mathrm{M}$ (Fig. 1c).

\section{Production of oestradiol from DHEAS}

The addition of DHEAS to granulosa cells caused a significant increase in oestradiol accumulation in the medium. This was maximal at $48 \mathrm{~h}$ and gradually declined thereafter. DHEAS increased oestradiol accumulation in a dose-dependent manner, with no change in progesterone production at any dose. The addition of $1 \mu \mathrm{M}$ DHEAS produced a 150-fold increase in oestradiol above basal levels. Similar results were seen in a further experiment in which androstenedione levels were also measured (Fig. 2a).

Incubation of the cells with gonadotrophins and a range of doses of DHEAS produced contrasting results. There was again a dose-related effect of DHEAS on oestradiol production. LH had no additional effect on conversion of $0 \cdot 1 \mu \mathrm{M}$ DHEAS to oestradiol, but caused a dose-related increase in conversion of 1.0 and $10 \mu \mathrm{M}$ DHEAS (Fig. 2b). In contrast, there was no consistent effect of FSH on oestradiol production from any dose of DHEAS in three experiments (data not shown).

The effects of DHEAS on oestradiol production by a pool of cells from small follicles ( $<6 \mathrm{~mm}$ in diameter) or individual follicles of 7 and $9 \mathrm{~mm}$ from an unstimulated 
ovary in the follicular phase of the cycle are shown in Fig. 2c. There were insufficient cells to perform full dose-responses in the latter two cases. There was a

(a)

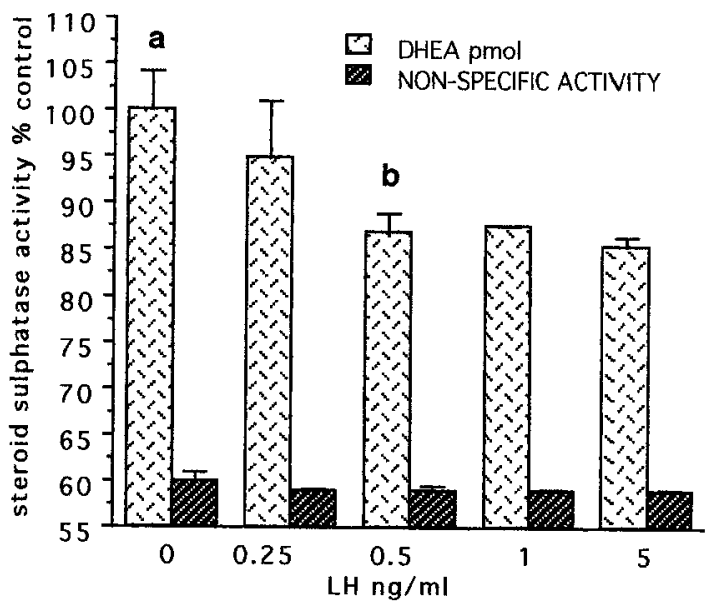

(b)

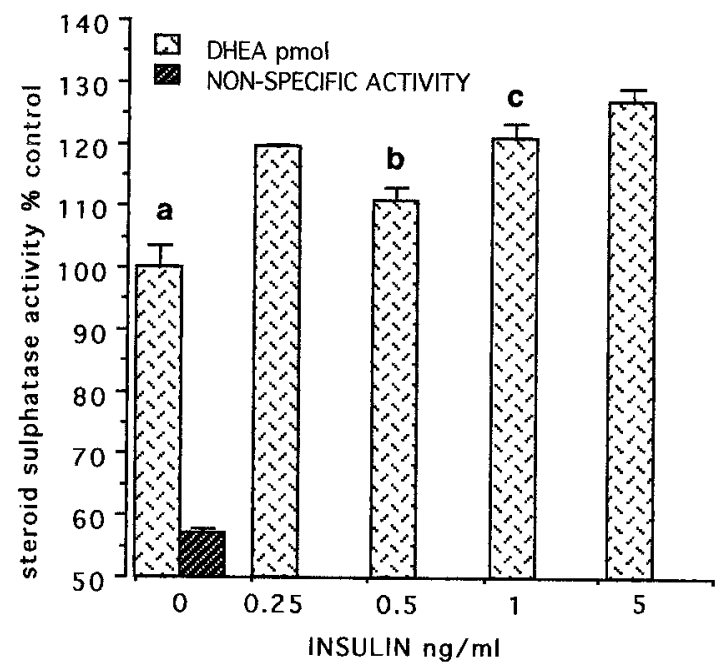

(c)

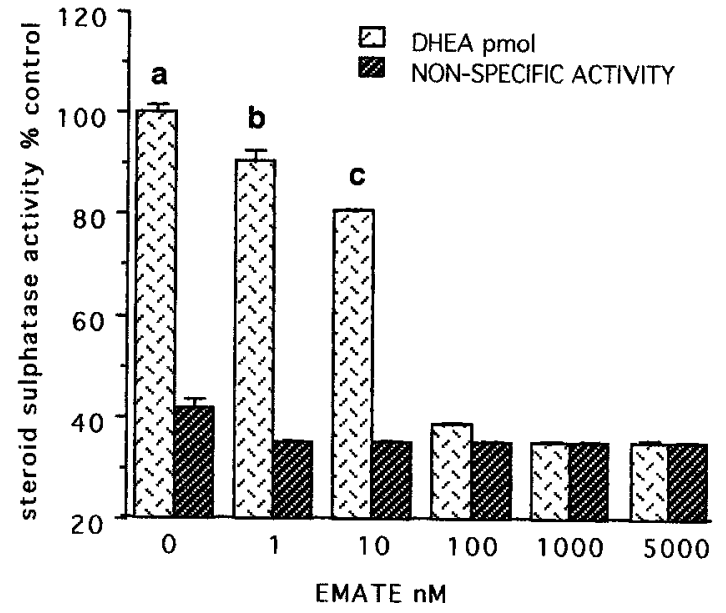

significant dose-related increase in oestradiol in each case with the activity being highest in the cells from the $7 \mathrm{~mm}$ follicle.

\section{Discussion}

This is the first demonstration that human granulosa cells are a site of significant steroid sulphate sulphatase activity. This concurs with the previous findings in which preparations of homogenized whole follicles were found to possess this activity (Haning et al. 1990, Patwardhan \& Lanthier 1972). We have also demonstrated that the activity is hormonally regulated. Surprisingly, incubation of the cells with LH appeared to have an inhibitory effect on the conversion of DHEAS to DHEA. The granulosalutein cells used in this part of the study are responsive to LH rather than FSH (Schipper et al. 1993) and progesterone secretion was increased by $\mathrm{LH}$ in the medium collected from corresponding wells prior to assessment of sulphatase activity. The data showing inhibition of sulphatase activity by LH when measured by assay and yet stimulation of conversion of DHEAS to DHEA appear contradictory. The disparity may be explained by the much higher concentration of substrate used in the latter experiments.

Insulin was consistently found to stimulate the conversion of DHEAS to DHEA in granulosa cells in our study. We and others have previously shown other effects of insulin in these cells, in terms of increased steroidogenesis and enhancement of gonadotrophin-stimulated oestradiol production (Garzo \& Dorrington 1984, Willis \& Franks 1995, Willis et al. 1996). In contrast, Nestler and colleagues (1987) studied the effects of insulin on serum DHEAS levels in women during a hyperinsulinaemiceuglycaemic clamp and found that insulin had a suppressive effect. When these findings were further investigated by repeating the study in men, both DHEAS and DHEA levels fell progressively and proportionally (Nestler et al. 1989). Interestingly, androstenedione levels also fell in

Figure 1 Sulphatase activity measured by production of DHEA from DHEAS substrate $(31 \mathrm{nM})$ in granulosa cells cultured in the presence or absence (control) of (a) $\mathrm{LH}$ at $0 \cdot 25-5 \mathrm{ng} / \mathrm{ml}$, (b) insulin at $0 \cdot 25-10 \mathrm{ng} / \mathrm{ml}$ or (c) the specific sulphatase inhibitor EMATE at $1-5000 \mathrm{nM}$. The assay incubation period was $4 \mathrm{~h}$. Bars represent the means and S.E.S of quadruplicate wells. Results are expressed as a percentage of control values. The mean (S.E.) value of the control was $0.96(0.04), 0.28(0.1)$ and $0.315(0.005)$ pmol DHEA and metabolites for $(a),(b)$ and $(c)$ respectively. The amount of product was reduced in the presence of $\mathrm{LH}$ (a vs $b$ $P<0.01$ ) and EMATE (a vs b $P<0.01$; a vs $\mathrm{c} P<0.001$ ), but increased in the presence of insulin ( $a$ vs $b P<0.05$; $a$ vs $c$ $P<0 \cdot 001)$. Non-specific activity was consistently low throughout. Results show representative responses from three similar experiments in each case, and all comparisons made by Student's t-test. 
these men. The authors concluded that the mechanism was unlikely to be one of stimulation of desulphation/ hydrolysis of DHEAS but, in contrast to our studies, was a direct effect on the adrenal.

We were unable to find any consistent effects of FSH on the conversion of DHEAS to other steroids. This finding was not unexpected as this experiment was only carried out in granulosa-lutein cells which have a noted variability in, or lack of response to, FSH (Schipper et al. 1993).

(a)

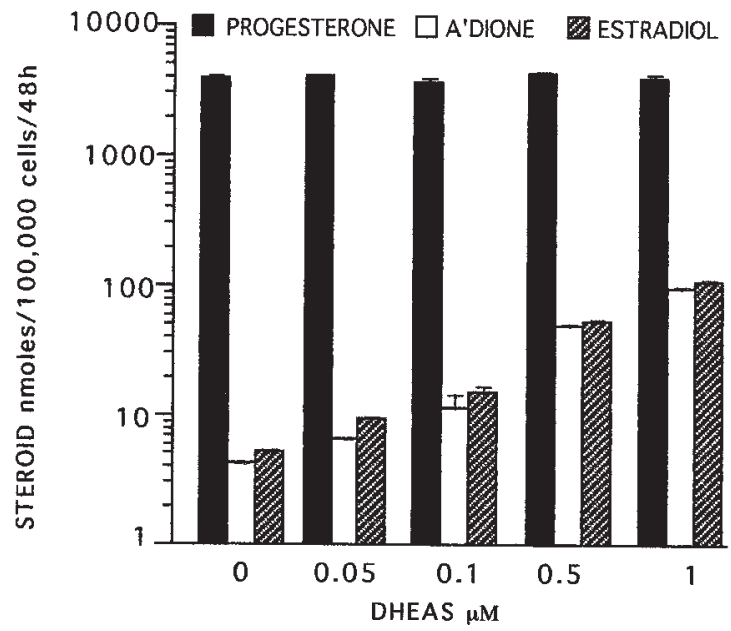

(b)

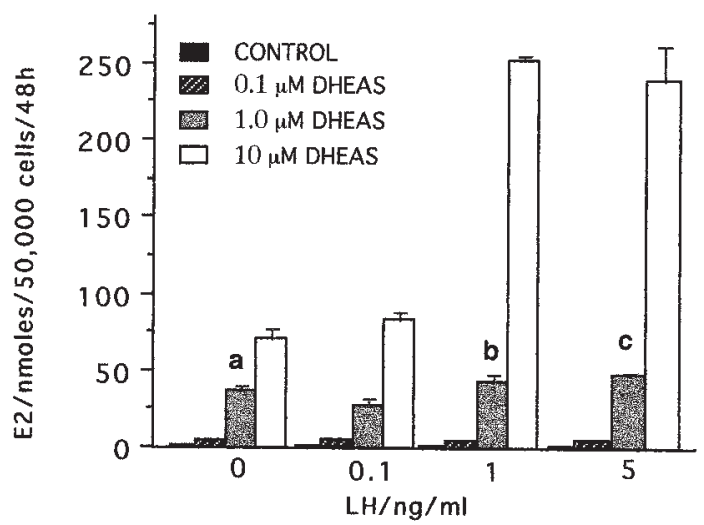

(c)

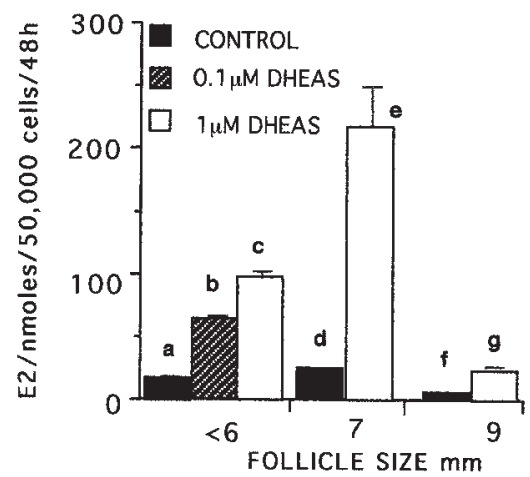

The demonstration of an increase in androstenedione as well as oestradiol in response to DHEAS infers that testosterone levels also increased as this is the likely steroid intermediary. Again this is in agreement with studies by Haning which showed that both tritiated androstenedione and testosterone were present in follicular fluid when patients were infused with tritiated DHEAS (Haning et al. 1991). Although we have not directly demonstrated production of oestradiol from the added DHEAS this is the only likely source of the steroid as granulosa cells in culture normally secrete only very small amounts of androgens into the medium and in the absence of androgen substrate, oestradiol production is low or undetectable (Mason \& Franks 1992).

It was found that DHEAS also increased the production of oestradiol in the granulosa cells which were derived from follicles of $9 \mathrm{~mm}$ diameter or less. There was variation between the granulosa cells from different sized follicles which is consistent with our previous findings that aromatase activity increases exponentially with follicle size (Mason et al. 1994). The granulosa cells from the $9 \mathrm{~mm}$ follicle showed less aromatase activity than those from the smaller follicles, the most likely explanation being that the $9 \mathrm{~mm}$ follicle was atretic. This was supported by the fact that only 280000 granulosa cells were derived from this follicle compared with the expected number of more than 2000000 in a healthy follicle of this size (McNatty et al. 1979). The conversion of DHEAS to oestradiol by the granulosa cells from the $7 \mathrm{~mm}$ follicle was $20 \%$, in comparison to approximately $12 \%$ by the luteinized granulosa cells. This suggests that the hypothesis that follicles utilize DHEAS from the circulation during the late follicular phase at the time when the requirement for steroid precursors is at a maximum may not be correct, as these results showed that the activity was, if anything, increased in small follicles. As far as we are aware there are no other data comparing sulphatase activity in healthy or atretic follicles.

Figure 2 Results shown in (a) and (b) are from experiments carried out in luteinized granulosa cells and are representative of three similar experiments in each case. Bars represent means \pm S.E.S. (a) Steroid production in response to a range of doses of DHEAS from 0.05 to $1 \mu \mathrm{M}$. Note the logarithmic scale. There was a significant dose-related increase in oestradiol and androstenedione $(P<0.01$ in each case, ANOVA) with no effect on progesterone. (b) Effect of a range of doses of $\mathrm{LH}(0 \cdot 1-1 \cdot 0 \mathrm{ng} / \mathrm{ml})$ on addition of DHEAS. The dose of DHEAS is given in the key. There was a significant increase above basal in oestradiol production at each level of DHEAS at all doses of $\mathrm{LH}(P<0 \cdot 001$, ANOVA). Only the higher doses of LH were effective at lower levels of DHEAS (a vs $b$ and a vs c $P<0 \cdot 1$, Student's $t$-test) and LH had no effect on the lowest dose of DHEAS. (c) Oestradiol production in response to addition of two doses of DHEAS in granulosa cells pooled from several follicles $<6 \mathrm{~mm}$ in diameter or from two individual follicles of 7 and $9 \mathrm{~mm}$ from an unstimulated ovary in the follicular phase of the cycle ( $a$ vs b and a vs $c$ $P<0 \cdot 001, d$ vs e and f vs $g, P<0 \cdot 0001$, Student's $t$-test). 
We have demonstrated that utilization of DHEAS may be a physiological process occurring in normal folliculogenesis, however this finding may also be of importance in disease states. DHEAS was found to provide $90 \%$ of the circulating androstenediol in post-menopausal women which may be a more important promoter of tumour growth than oestradiol or oestrone sulphate (Dauvois \& Labrie 1989). It has been suggested that steroid sulphatase inhibitors could be therapeutically effective in endocrinedependent tumours (Reed \& Purohit 1993). EMATE has been shown to inhibit irreversibly both oestrone sulphatase and DHEA sulphatase in breast cancer cells (Purohit et al. 1995b). We have demonstrated that EMATE was also successful in blocking DHEA sulphatase activity of human granulosa cells. This could prove to be clinically important in oestrogen-dependent tumours in pre-menopausal women.

In conclusion, these results have demonstrated for the first time that the sulphatase enzyme is present in human granulosa cells. Cells collected from follicles in the follicular phase of the cycle as well as luteinized cells from preovulatory follicles were able to utilize DHEAS as a precursor for oestrogen biosynthesis and this process was stimulated by the pituitary hormone $\mathrm{LH}$ and blocked by a sulphatase inhibitor. This may be of physiological importance in normal folliculogenesis by increasing testosterone levels when required and may also be relevant in oestrogen-dependent tumour growth.

\section{Acknowledgements}

These data were presented in part at the Society for Endocrinology's 186th and 187th Meetings (Walker et al. 1995, Bonser et al. 1996).

\section{References}

Baulieu EE, Corpechot C, Dray F, Emiliozzi R, Lebeau MC, Mauvais-Jarvis P \& Robel P 1965 An adrenal secreted 'androgen' dehydroepiandrosterone sulphate. Its metabolism and a tentative generalization on the metabolism of other steroid conjugates in man. Recent Progress in Hormone Research 21 411-494.

Bonser J, Mason HD \& Franks S 1996 Utilisation of dehydroepiandrosterone sulphate (DHEAS) as an oestrogen precursor in the human granulosa cell. Proceeding of the 187th Meeting of the Society for Endocrinology, London 1996. Journal of Endocrinology 150 (Suppl) P91.

Cumming DC, Rebar RW, Hopper BR \& Yen SSC 1982 Evidence for an influence of the ovary on circulating dehydroepiandrosterone sulphate levels. Journal of Clinical Endocrinology and Metabolism 54 1069-1071.

Dauvois S \& Labrie F 1989 Androstenedione and androst-5-ene-3 $\beta$, $17 \beta$ diol stimulate DBMA-induced rat mammary tumours - role of aromatase. Breast Cancer Research Treatment 13 61-69.

Dehenin L, Jondet M \& Scholler R 1987 Androgen and 19-norsteroid profiles in human preovulatory follicles from stimulated cycles: an isotope dilution mass spectrometric study. Journal of Steroid Biochemistry 26 399-405.
Duncan L, Purohit A, Howarth NM, Potter BVL \& Reed MJ 1993 Inhibition of steroid sulphatase activity by oestrone-3methylthiophosphonate: a potential therapeutic agent in breast cancer. Cancer Research 53 298-303.

Garzo VG \& Dorrington JH 1984 Aromatase activity in human granulosa cells during follicular development and the modulation by follicle-stimulating hormone and insulin. American Journal of Obstetrics and Gynaecology 5 657-662.

Gilling-Smith C, Willis DS, Beard R \& Franks S 1994 Hypersecretion of androstenedione by isolated theca cells from polycystic ovaries. Journal of Clinical Endocrinology and Metabolism 79 1158-1165.

Haning RV 1995 Dehydroepiandrosterone sulphate. Editor's formulation. Seminars in Reproductive Endocrinology 13 299-303.

Haning RV, Austin CW, Carlson IH, Kuzma DL \& Zweibel WJ 1985 Role of dehydroepiandrosterone sulphate as a prehormone for ovarian steroidogenesis. Obstetrics and Gynecology 65 199-205.

Haning RV, Chabot M, Flood CA, Hackett R \& Longcope C 1989 Metabolic clearance rate of dehydroepiandrosterone sulphate (DS) its metabolism to dehydroepiandrosterone, androstenedione, testosterone and dihydrotestosterone and the effect of increased plasma DS concentration on DS metabolic clearance rate in normal women. Journal of Clinical Endocrinology and Metabolism 69 $1047-1052$.

Haning RV, Hackett RJ, Boothroid RI \& Canick JA 1990 Steroid sulphatase activity in the human corpus luteum, stroma and follicle: comparison to activity in other tissues and the placenta. Journal of Steroid Biochemistry 36 175-179.

Haning RV, Flood CA, Hackett RJ, Loughlin JS, McClure N \& Longcope C 1991 Metabolic clearance rate of dehydroepiandrosterone sulphate, its metabolism to testosterone and its intrafollicular metabolism to DHEA, androstenedione, testosterone and dihydrotestosterone in vivo. Journal of Clinical Endocrinology and Metabolism 72 1088-1095.

Hardy K, Robinson FM, Paraschos T, Wicks R, Franks S \& Winston RML 1995 Normal development and metabolic activity of preimplantation embryos in vitro from patients with polycystic ovaries. Human Reproduction 10 2125-2135.

Mason HD \& Franks S 1992 Androstenedione accumulation in human granulosa cell cultures from normal and polycystic ovaries. Journal of Endocrinology 132 (Suppl) 308.

Mason HD, Margara R, Winston RML, Beard RW, Reed MJ \& Franks S 1990 Inhibition of oestradiol production by epidermal growth factor in human granulosa cells of normal and polycystic ovaries. Clinical Endocrinology 33 511-517.

Mason HD, Willis DS, Beard RW, Winston RML, Margara R \& Franks S 1994 Estradiol production by granulosa cells of normal and polycystic ovaries: relationship to menstrual cycle history and concentrations of gonadotrophins and sex steroids in follicular fluid. Journal of Clinical Endocrinology and Metabolism 79 1355-1360.

McNatty KP, Smith DM, Makris A, Osathanondh R \& Ryan KJ 1979 The microenvironment of the human antral follicle: interrelationships among the steroid levels in antral fluid, the population of granulosa cells and the status of the oocyte in vivo and in vitro. Journal of Clinical Endocrinology and Metabolism 49 851-860.

Nestler JE, Clore JN, Strauss III JF \& Blackgard WG 1987 The effects of hyperinsulinaemia on serum testosterone, progesterone, dehydroepiandrosterone sulphate and cortisol levels in normal women and in a woman with hyperandrogenism, insulin resistance and acanthosis nigricans. Journal of Clinical Endocrinology and Metabolism 64 180-184.

Nestler JE, Usiskin KS, Barlascini CO, Welty DF, Clore JN \& Blackard WG 1989 Suppression of serum dehydroepiandrosterone sulphate levels by insulin: an evaluation of the possible mechanisms. Journal of Clinical Endocrinology and Metabolism 69 1040-1046.

Patwardhan VV \& Lanthier A 1972 A comparative study of utilisation in vitro of tritiated dehydroepiandrosterone sulphate for the formation of androgens and estrogens by the follicular and stromal compartments of human ovaries. Steroids 20 761-771. 
Purohit A, Williams GJ, Howarth NM, Potter BVL \& Reed MJ 1995 Inactivation of steroid sulfatase by an active site-directed inhibitor, estrone-3-O-sulphamate. Biochemistry 34 11508-11514.

Purohit A, Williams GJ, Roberts CJ, Potter BV L \& Reed MJ $1995 b$ in vivo inhibition of estrone sulphatase and dehydroepiandrosterone sulphatase by estrone-3-O-sulphamate. International Journal of Cancer 63 106-111.

Reed MJ \& Purohit A 1993 Sulphatase inhibitors: the rationale for the development of a new endocrine therapy. Reviews on Endocrine-Related Cancer 45 51-62.

Reed MJ, Purohit A, Howarth NM \& Potter BVL 1994 Steroid sulphatase inhibitors: a new endocrine therapy. Drugs of the Future 19 673-680.

Schipper I, Fauser BC, van Gaver EB, Zarutskie PW \& Dahl KD 1993 Development of a human granulosa cell culture model with follicle stimulating hormone responsivenes. Human Reproduction $\mathbf{8}$ 1380-1386.
Walker J, Willis DS, Purohit A, Reed M, Mason HD \& Franks S 1995 Steroid sulphatase activity in human granulosa cells. Proceeding of the 186th Meeting of the Society for Endocrinology, London 1995. Journal of Endocrinology 147 (Suppl) P93.

Willis DS \& Franks S 1995 Insulin action in human granulosa cells is mediated via the insulin receptor and not the insulin-like growth factor receptor. Journal of Clinical Endocrinology and Metabolism 80 3788-3790.

Willis DS, Mason HD, Gilling-Smith C \& Franks S 1996 Modulation by insulin of follicle stimulating hormone and luteinizing hormone actions in human granulosa cells of normal and polycystic ovaries. Journal of Clinical Endocrinology and Metabolism 81 302-309.

Received 31 August 1999

Revised manuscript received 3 July 2000

Accepted 2 August 2000 